\title{
基礎代謝の季節的変動に関寸る研究
}

\section{Seasonal Variation in Basal Metabolism}

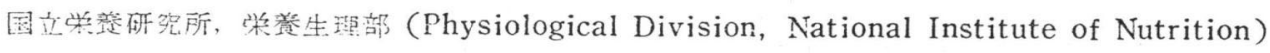

$\begin{array}{llllll}\text { 鈴林慎次郎 } & \text { (S. Suzuki) } & \text { 長 嶺 晋 吉 } & \text { (S. Nagamine) } \\ \text { 大島寿美子 } & \text { (S. Oshima) } & \text { 山川喜 久 江 } & \text { (K. Yamakawa) } \\ \text { 河 田 正治 } & \text { (S. Kawada) } & \text { 久 我 達 郎 } & \text { (T. Kuga) }\end{array}$

Table 1 gives the basal metabolism values of five subjects(laboratory research workers)which were observed twice a month for a period of 4-6 years. Figure 1 illustrates the correlation between the total of the above average monthly values and the average external temperature of each month.

From the above table and figure we can say that BM levels show an inverse proportional relationship to the average external temperature.

This is further verified on investigating the quantitative relationship between the BM fluctuation percentage and the average external temperature; it is found from the readings of the interior scales (percentages on temperature scale are calculated on absolute temperature) on both axes that the two are in complete agreement.

This quantitative relationship between $\mathrm{BM}$ and external temperature is very interesting, though it is based on present Japanese daily life conditions and may be inapplicable to people of other nations.

From these data the seasonal BM variation of the Japanese race is quantitatively estimated as

$1 / 273$ for a variation of $1^{\circ} \mathrm{C}$, that is slightly lowere than 4 percent for a variation of $10^{\circ} \mathrm{C}$. Furthermore, if there is significance in the rise and fall of seasonal variation BM curves, the slight rise observed in April and July may be explained by the light clothing during the seasonal change between spring and summer, while the change to heavy clothing may be the cause of the fall in December.

〔はしがき〕基礎代謝（BM）の季節的変動に関する研究は洋の東西をとわずこれ索でかなり多く発表され ている。

わj゙国においても越智・喜瀬，藤本，白并，鈴木等は東京において，大柴は京都で，福原は大阪で，上男は 德島で, 佐ヶ木は熊本において, 各ヶ同一被験者について月別にBMを測定し, 季節の影響を報告している。 そして、これらの研究は気候生理学の対象として與味あるばかりでなく, 実用面においてもカロリ一所要量の 基準值決定に基礎資料を提供している。 


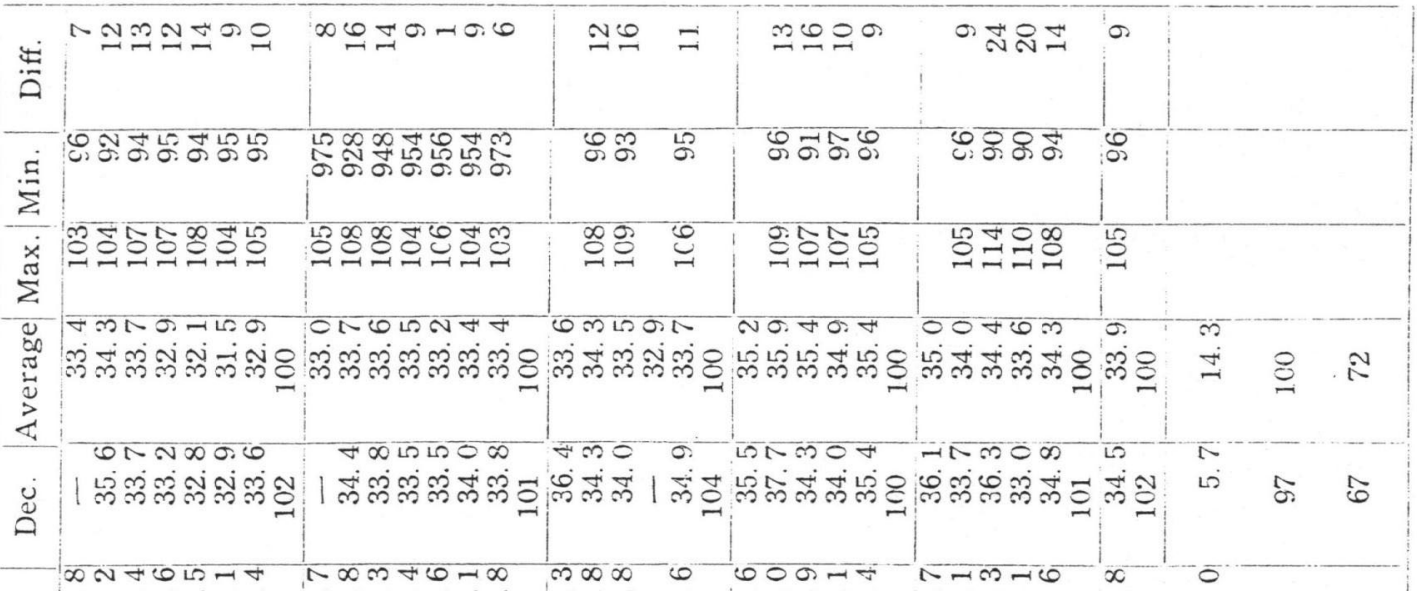

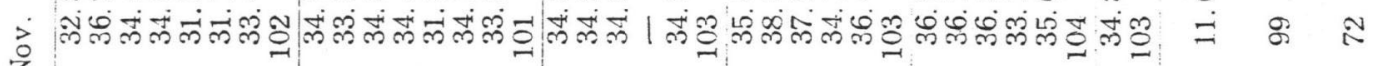
z

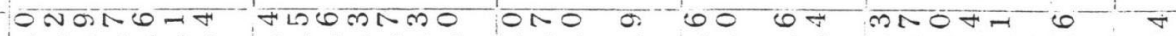

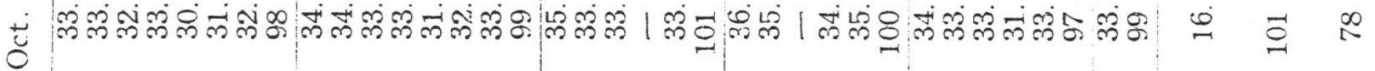

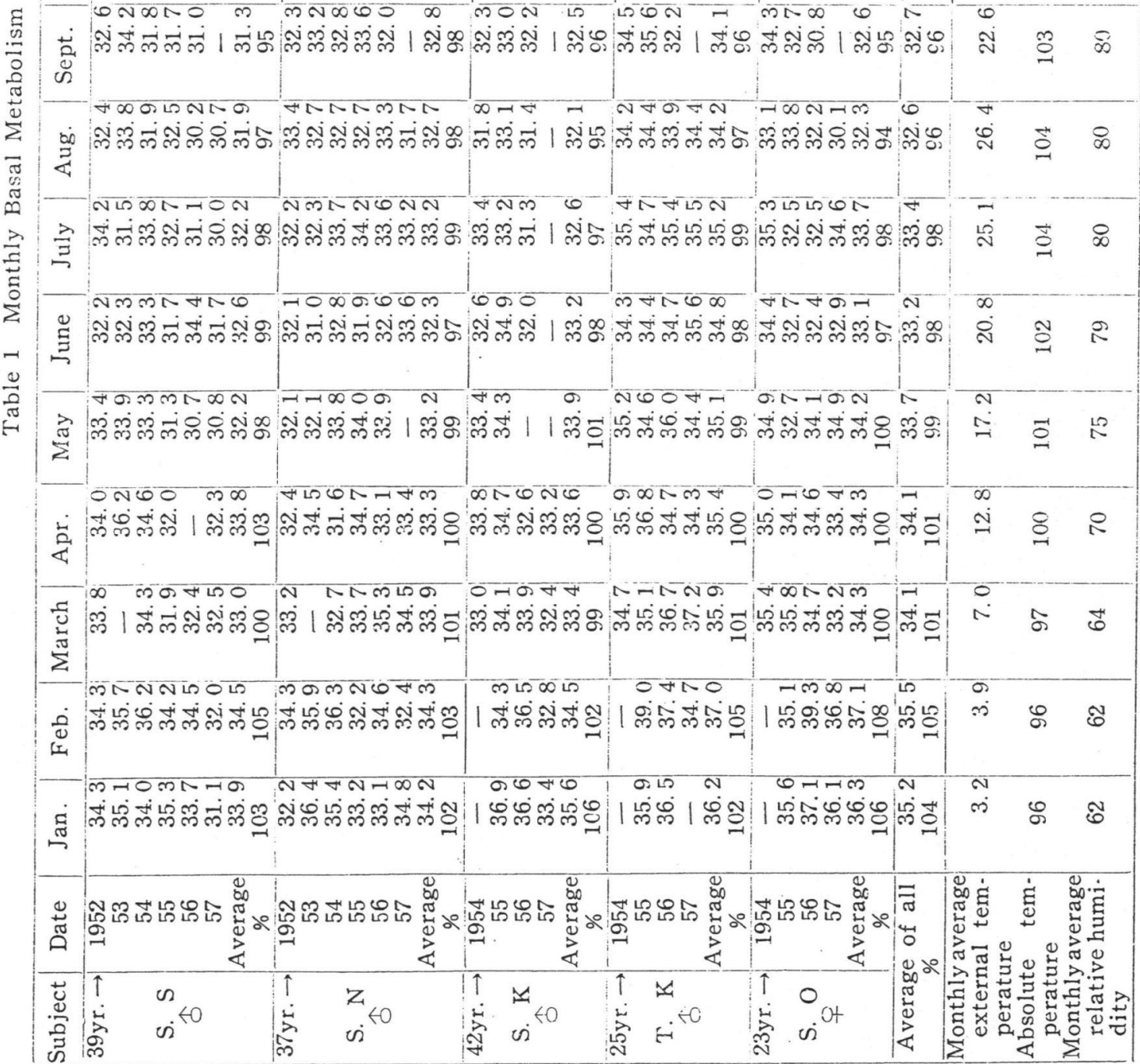


たな゙この実験は同一人について長期にわたり継続されなければならないたふ，測定人数，測定期間，測定 回数等の実験条件において制約されがちである。したがつて，この種の資料を集積するには多くの研究者の協 力が望ましい。われわれがその後の資料を整理して再び発表する意図もここにある。

〔方法】当研究室では1949年以降研究者自身のBMを毎月 2 日才゙つ定期的に測定してきた。その一部につい ては既に報告したが，今回は大戦の影響をうけている1951年以前の資料を除き，更にその中でも4年間以上継 続して測定したもの男子4名，女子1名についてBMの季節的変動を中心にして集計した。

〔成績並びに考察〕各被唡者の年度別月別測定值は第 1 表に, 他の報告者との比較は第 2 表に, また月別総 平均值之外気温之の関係注第 1 図比示されている。

(1) 個人別にみる上 (第 1 表);

S. S. : 各年度の最大最小の較差は 7 〜 14\%であり，年度によりかなりの差異が認められるが，6年間の月 別平均值は年閒平均に対し 105〜95\%にあつて，その差は10\%である。

S. N. : 各年度の最大最小の較差は 9 14\%であるが, 6 年間の月別平均值は 103〜98\%でその差は $6 \%$ 之 なり, 上゙の年度の較差より著し々小さい。これは各年度の変動の波が互に打消し合うためである。

S. K. : 3 年 2 力月間の月別平均值汢 106 95\%で，その較差は $11 \%$ 。

T. K. : 4 年閁の月別平均值は 105 96\%でその較差は $9 \%$ 。

S. O. : 4 年問の月別平均值は 108〜94\%でその較差は14\%と他よりかなり大きいが、これは女性の月経に 伴う B Mの週期的変動を想えば当然であろう。

しかし，何れにしても，各被検者において数年閒の月別平均值の年較差が各年度別較差にくらべかなり小さ いことは注目すべきである。このことは，個人の年間変動を見る場合にも 1 年間だけの観察では 1 例報告にす ぎないこと在示唆しているのではなかろうか。さらに，BMの日差をも教慮にいれると毎月の測定回数の多い ことも望ましい条件であろう。

また，各人の数年問の月別平均值の年較差に 6 14\%と著しい個人差が認められることは，B Mが生体の基 本的エネルギー代謝を表わすだけに気候に対する基本的反応の個人差を示すものとして重要である。そしてこ 第2 表著者別基礎代謝季節変動 (年間平㚬值に対する月別百分率)

\begin{tabular}{|c|c|c|c|c|c|c|c|c|}
\hline & $\begin{array}{l}\text { 鈴木等 } \\
\text { 東 京 }\end{array}$ & $\begin{array}{l}\text { 白 并 } \\
\text { 東 京 }\end{array}$ & $\begin{array}{l}\text { 藤 本 } \\
\text { 東 京 }\end{array}$ & $\begin{array}{l}\text { 越智等 } \\
\text { 東 }\end{array}$ & $\begin{array}{l}\text { 大 柴 } \\
\text { 京 都 }\end{array}$ & $\begin{array}{ll}\text { 福 } & \text { 原 } \\
\text { 大 } & \text { 阪 }\end{array}$ & 卡 田 & $\begin{array}{l}\text { 佐々木 } \\
\text { 熊 本 }\end{array}$ \\
\hline $\begin{array}{cc}1 & \text { 月 } \\
2 & \text { 月 } \\
3 & \text { 月 } \\
4 & \text { 月 } \\
5 & \text { 月 } \\
6 & \text { 月 } \\
7 & \text { 月 } \\
8 & \text { 月 } \\
9 & \text { 月 } \\
10 & \text { 月 } \\
11 & \text { 月 } \\
12 & \text { 月 }\end{array}$ & $\begin{array}{r}104 \\
105 \\
101 \\
101 \\
99 \\
98 \\
98 \\
96 \\
96 \\
99 \\
103 \\
102\end{array}$ & $\begin{array}{r}106 \\
107 \\
100 \\
98 \\
97 \\
97 \\
96 \\
97 \\
97 \\
99 \\
103 \\
105\end{array}$ & 103 & $\begin{array}{r}109 \\
104 \\
101 \\
97 \\
96 \\
94 \\
97 \\
99 \\
97 \\
103 \\
105 \\
104\end{array}$ & 92 & $\begin{array}{r}106 \\
105 \\
100 \\
99 \\
98 \\
96 \\
97 \\
101 \\
99 \\
96 \\
103 \\
104\end{array}$ & $\begin{array}{r}105 \\
104 \\
101 \\
99 \\
97 \\
97 \\
96 \\
97 \\
99 \\
100 \\
102 \\
103\end{array}$ & $\begin{array}{r}108 \\
107 \\
106 \\
101 \\
99 \\
94 \\
91 \\
92 \\
91 \\
98 \\
105 \\
107\end{array}$ \\
\hline $\begin{array}{lll}\text { 職 } & & \text { 業 } \\
& \text { 性 } & \\
\text { 人 } & & \text { 数 } \\
\text { 期 } & & \text { 間 } \\
\text { 回 } & & \text { 数 } \\
\text { 発 } & \text { 表 } & \text { 年 }\end{array}$ & $\begin{array}{c}\text { 研究者 } \\
\text { 男・女 } \\
5 \\
4 \sim 6 \text { 年 } \\
\text { 月 } 2 \text { 回 } \\
1959\end{array}$ & $\begin{array}{c}\text { 研究者 } \\
\text { 男 } \\
1 \\
2 \text { 年 } \\
\text { 月10数回 } \\
1939\end{array}$ & $\begin{array}{c}\text { 学 生 } \\
\text { 男 } \\
12 \\
2 \text { 年 } \\
\text { 計89例 } \\
1936\end{array}$ & $\begin{array}{c}\text { 成 } \\
\text { 男 } 9 \text { 女 } \\
9 \\
1 \text { 年 } \\
\text { 月 } 1 \text { 回 } \\
1932\end{array}$ & $\begin{array}{c}\text { 学 生 } \\
\text { 研究者 } \\
\text { 畕 } \\
9 \\
1 \text { 年 } \\
\text { 月 } 2 \text { 年 } \\
1957\end{array}$ & \begin{tabular}{|c} 
軽作業者 \\
男 \\
2 \\
1 年 \\
月 4 回 \\
1950
\end{tabular} & $\begin{array}{c}\text { 中学生 } \\
\text { 男 } \\
9 \\
1 \text { 年 } \\
\text { 月 } 1 \text { 回 } \\
1953\end{array}$ & $\begin{array}{c}\text { 成 人 } \\
\text { 男 } \\
5 \\
3 \text { 年 } \\
\text { 月数回 } \\
1954\end{array}$ \\
\hline
\end{tabular}


れぶ他の生理的現象の気候

Fig. 1

反応と密接な関係をむつこ とが想像されるが，それに 関しては他日発表する予定 である。

かつ、このように個人差 が認められることは日本人 の平均值救好場合被検 者の多いことも一つの重要 な条件であることを示唆し ている。

（2）月別全員平均值につ いてみると（第1，2表, 第 1 図)；

第 1 図のようにB Mは平 均外気温に逆比例して変動 し, しかも両者の変動を量

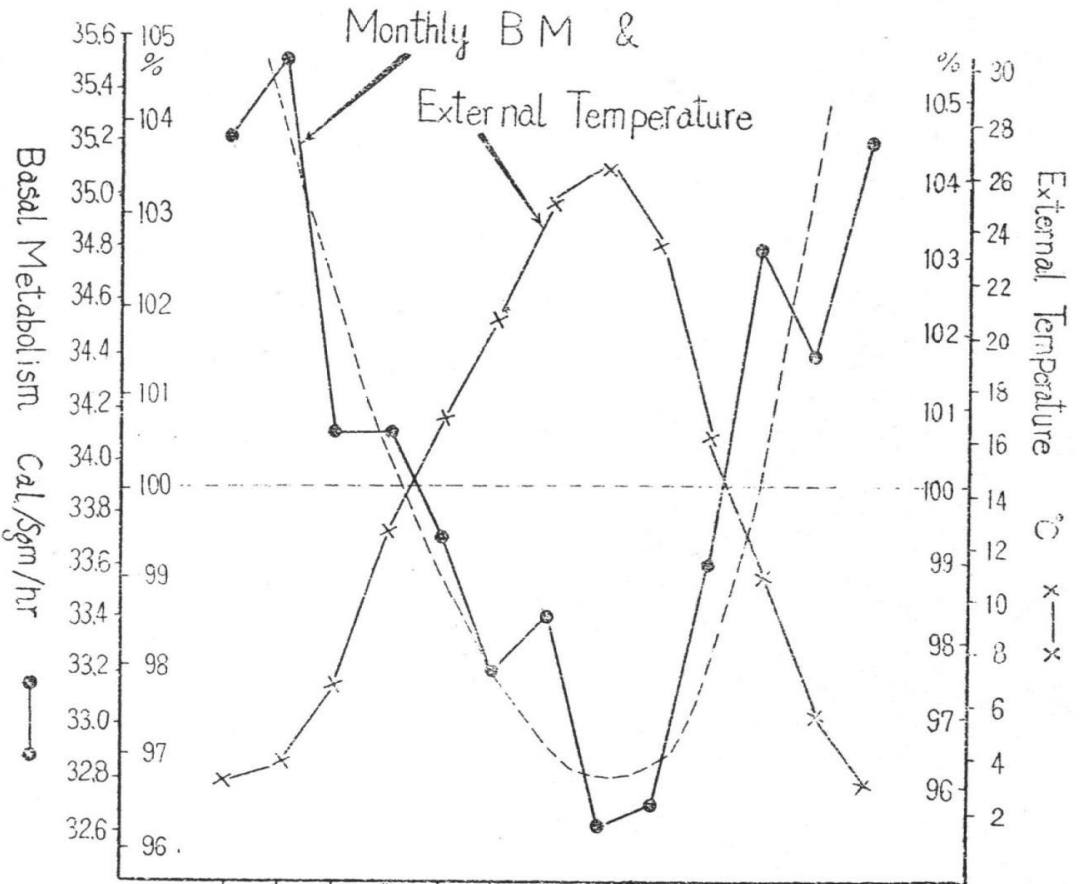

Jan. Feb.Mar. Afr. May. Jun. Jai. Auro Sep. Rat. Noy. Dec.ran.

的関係において検討するため両繸軸の内側目盛を比較すると， B Mの変動\%と外気絶対温度の変動％とのゆは 殆んど一致している。

即ち, B Mの季節的変動は量的にみると，

$1^{\circ} \mathrm{C}$ の変化に対し約 $1 / 273,10^{\circ} \mathrm{C}$ の変化に対し約 $3 \sim 4 \%$ に当る。

この量的関係は，この研究者の日常生活状態殊にその被服気候や室内気候の下に成立するのであるから，万 人共通の法則とはいえないが，かつて報告した日本全国における BMと気候との関係でみられた値 $\left(10^{\circ} \mathrm{C}\right.$ 以

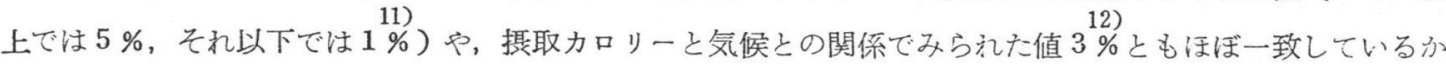
ら，かなり普遍性のある数字ではなからうか。

なお，季節的変動曲線の細い起伏についてその意味ありとすれば，4月と 7 月のやや増加する理由として季 節の変わり目で薄着になること，12月の低下の原因としては冬服に変わることなな゙があげられよう。

（3）他の報告值との比較 (第 2 表);

次にこのわれわれの值をこれまでに報告された文献值と比較する。

まず東京において測定されたものをみると，年間の最大最小較差において，越智の $15 \%$ はや離れている が，藤本 $10 \%$, 白井 $11 \%$, 著者等 $9 \%$ の值はほぼ一致しており，しふも著者等や白井の測定回数の多いことを 考虑に入れると，約 $10 \%$ 考えて大過なからう。

また，大阪における福原の10\%や四国における上王の $9 \%$ も前記の值と全く一致している。ただ京都におけ る大棐の成績と熊本における佐々末）成績は何れも17\%の年間較差を示し，上記の数字よりかなり大きい。 このことについて佐ヶ木は, 熊本或は京都のような外気温の日較差が大で然も年平均気温も比較的高い所で は，かような代謝の大きな年間変動が現われるものと思われると述べている。

ただ，東京と京都・大阪における日較差は第3 表に見るようにに，1月では殆えど認められず，8月において 
第3 表 各地の気温（東京天文台：理科年表 1958，1921 1950年間の統計）

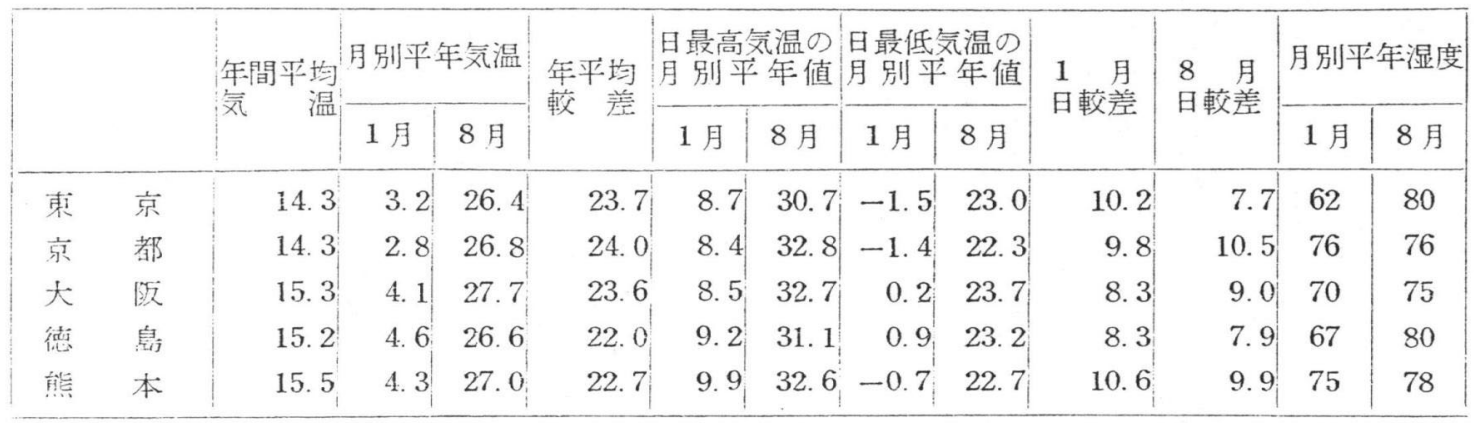

も2 3 ${ }^{\circ} \mathrm{C}$ に過ざないので, 両地 BMの差の原因として何加他の因子も考えられるのでなかるうか。たとえ ば，(1)で述べたように，今回の成績を各年度別にみると年較差のゆはかなり大きいが，数年間を別に平均し た場合のゆはどの被検者に扔いても著しく小さくなつていることなども一つの因子としてあげられないだろう 和。

〔さすび〕研究員 5 名について 4 6 年間每月 2 回ずつ測定した基礎代謝についてその季節的変動を中心に 検討した。その結果, BM外外気温に逆比例して変動し, 量的には $10^{\circ} \mathrm{C}$ の変化に対し $3 \sim 4 \%$ 割合で增減 ナること劣明かにした。

各月の測定值苍年間平均值们換算与る場合の補正係数を示した。

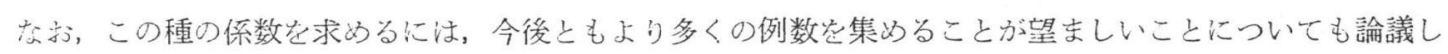
た。

文南

1) 越智・喜瀬: 穈応医学, 12, 2199 (1931).

2) 藤本萯喜: 栄羔研究所報告, 8, 113 (1935).

3) 白井伊三郎: 体热研究， ?，2 (1939).

4) 鈴木・長額・大島・山川: 栄盖学雑誌, 12, 33 (1954).

5) 大柴通: Jap. J. Fhysiol. 7, 355 (1957).

6) 福原丈吉 : 栄養と食糧, 3, 65 (1950).

7) 上田豊晴：国民衛生，22，88 (1953).

8) 佳々木隆: 体質医学研究報告, 4, 439 (1954).

9) 鈴朴・長嶺・大島 : 栄養学雑誌, 10, 108 (1953).

10) 鈴木 - 長嶺・山川・大島: 栄養学雑誌, 11, 2 (1953).

11) 鈴朴・長嶺・河田・久我・大島・山川: 栄養学雑誌, 16, 173 (1958).

12) 河田正治：栄羪学雑誌, 11, 85 (1954). 